\title{
The Philosophy of Ecology as a Specific and Direct Method of Ecological and Humanistic Research and Management
}

\section{Lubov Vladyková}

Envigogika 10 (4) - Reviewed Papers/ Recenzované články

Published/ Publikováno 4. 12. 2015

DOI: $\underline{10.14712 / 18023061.498}$

\begin{abstract}
The philosophy of ecology is an intersectional, multi-discursive foundation, which covers a vast area characterised by an extensive research agenda, connecting a number of established scientific disciplines. It is our aim to highlight the interdisciplinary character of the problem under discussion, as well as the fact that different conceptions of the philosophy of ecology would be hard to sustain and difficult to respect if they did not respond to the findings of the latest research, be it in the field of ecology or in the field of philosophy. In order to be able to envisage a future for the Earth that would be sustainable in the long term, we need knowledge and we need to internalise a method for evaluating information that would enable us to discard irrelevant information in times of critical change.
\end{abstract}

\section{Key words}

philosophy of ecology, ecological science, ecological problem

\begin{abstract}
Abstrakt
Filozofická reflexia ekológie predstavuje prienikovú polydiskurzívnu bázu - čo značne rozširuje priestor s rozsiahlou výskumnou agendou, prechádzajúcou vedecky etablovanými oblast́ami. Naším ciel'om je upozornit́ na interdisciplinárny charakter skúmanej problematiky, ako aj na skutočnost', že koncepcie filozofie ekológie by boli táǎko obhájitel'né a rešpektované bez reflexie výsledkov súčasného vedeckého poznania tak $v$ oblasti ekologických vied ako aj filozofie. Aby sme mohli plánovat' dlhodobo udržatel'nú budúcnost' Zeme, potrebujeme vedomosti a potrebujeme integrovat spôsob, ktorým sú informácie ohodnotené, a ktorým sú neprínosné informácie odmietané $v$ obdobiach kritickej zmeny.
\end{abstract}

\section{Klíčová slova}

ekologická filozofie; ekologická věda; ekologický problém 
There is a saying that scientists need to study the philosophy of science as much as birds need to study ornithology. There certainly is a degree of truth in this claim, as a number of scientists do research without any formal training in philosophy. Nevertheless, I believe that this statement is not completely true. There are certain ways in which philosophy can become an inspiring and relevant counterpart to exact sciences, 'working shifts', so to speak, making possible the interdisciplinary research and practice required by the times we are living in.

Our age can definitely be distinguished from the previous periods in human history by the rise of organised science that it has witnessed and by the unparalleled pace of technological development. The number of emerging non-human entities - laboratory creations, 'hybrids', quasi-objects - has soared. What is symptomatic is how these changes are amplified when identifying our so-called knowledge-data-information society, the age of neoindividualism, etc. In this context, the opinion that our planet is undergoing a phase of probably unprecedented biotic impoverishment is voiced more and more frequently. The most pressing of the problems that humankind is currently facing, including overpopulation, a scarcity of energy resources, climate change, soil erosion, the gradual extinction of species, the threat of epidemics or of a war that could destroy all the hard-earned achievements of our civilisation, or even the recent stock-market fluctuations, are ecological or have profound ecological consequences.

We already know that "... natures are present, but with their representatives, scientists who speak in their name. Societies are present, but with the objects that have been serving as their ballast from time immemorial." (Kuhn, 1977: 188). We understand nature as 'represented' by science, because unlike in other fields of human activity, it is not the aim of science to change the world, but rather to change our idea of the world, which, however, has serious consequences for technology and engineering because the way in which we imagine the world affects our actions in that world. We can no longer understand the natural world merely as an arena in which human interactions take place, or as a value-neutral vector connecting the human moral agent with the non-human patient. Rather, it is a nature studied by natural science, and this is where the study of natural science from the point of view of the social sciences (excluding epistemological analysis in a narrow sense, which does not transcend the realm of terminological interpretation) comes into play, as such study implies that the nature described by biology, ecology, chemistry, physics, etc., is an entity which we approach through practical, socially-organised activity.

The aforementioned might be the source of philosophy's increased interest in ecology, noticeable over the course of the last thirty years, which reflects the importance of ecology throughout this period. This interest is complicated by the fact that ecologists do not agree on the answer to the underlying question: What is the domain of ecology? Many ecologists prefer a narrower, restrictive definition of ecology, which focuses on the behaviour of non-human organisms in natural environments (McIntosh, 1985; Kingsland, 2005). Others defend a wider, more expansive definition, which includes the study of the relationship between humans and the environment. This viewpoint poses a challenge to traditional ecology understood as a strictly biological science. Consequently, the understanding of the philosophy of ecology is partially dependent on whether we accept the narrower definition of ecology or the more expansive one. Within the restrictive paradigm, the philosophy of ecology deals with the conceptual and methodological problems of populations, societies and ecosystems. Within the more expansive paradigm it attempts to solve problems in the fields of social and human ecology (P. Shepard, 1969).

Humans are the most ecologically influential species on earth and the study of the ecological aspects of human behaviour and activity - including motivation, attitudes and 
conduct with regard to the environment - is a legitimate and significant part of ecology. Within this expansive paradigm, the line between ecology as science and ecology as a philosophical worldview becomes blurred. At the same time, the commitment to scientific methodology prevents ecology from turning into a mere spokesperson for a speculative or radical ecological philosophy.

In the broadest sense, philosophy of ecology is the philosophical enquiry into

(a) ecological phenomena;

(b) the scholarly disciplines studying these phenomena.

Ecological phenomena are discussed within various branches of ecology. This problematic, the usage of the term 'ecology', is used differently in different contexts. For example:

(a) ecology is a multifaceted discipline with a number of subfields, but on the whole it is meant to be a natural science (not a social science or a branch of the humanities), specifically a biological (not physical) science;

(b) ecology is a multifaceted discipline with a number of subfields, and it should be understood as an interdisciplinary field connecting physical, biological and social sciences and the humanities; it is a synthetic science and integrating ecologically relevant information at different spatial and temporal levels of organisation, including human social organisation, is one of its objectives.

In this regard, the goal which we have set for ourselves, and which is closely tied to the educational application of the present text, is more modest: it aims to present selected topics and concepts which have defined the philosophy of ecology from its beginnings and which serve as a foundation for its identification. This framework of knowledge includes different levels of maturity, because it depends on mutual respect and on the acknowledgement of diversity. It is our goal to promote common values ${ }^{1}$ in the field of education in order to support effort and sensibility in our mutual relationships and in our relationship to the natural world.

The topic in question has interdisciplinary and transdisciplinary implications. A number of problems addressed within the philosophical discourse of the philosophy of ecology are the result of a wider intellectual discussion which has helped, and is still helping, to design the discourse of the philosophy of ecology in the twentieth and twenty-first century. This is true especially of the debate between the holistic and the reductionist research traditions in ecology and in the philosophy of ecology.

Holistic research traditions which are based on the work of F. E. Clemens $(1935,1943)$ are grounded in the belief that, thanks to the level of their organisation, ecological systems are characterised by order, structure and regularity on the level of populations, communities

\footnotetext{
${ }^{1}$ A number of philosophers of science admit that there are values in science, i.e. epistemic values (Kuhn, 1977). All hypotheses are evaluated from the point of view of their accuracy, simplicity, scope, etc. Each of these values can be imprecise, or can be favoured over the others by the researcher who carries out the evaluation. Of course, it is the subject of a wider discussion how these values relate to one another. What is even more controversial is the claim of some philosophers that in addition to the epistemic values, there are also moral values in natural sciences, including ecology and conservation biology: K. Shrader-Frechette and Ed McCoy (1993).
} 
and ecosystems. The characteristic features of higher level systems influence the features and patterns of lower level ones. This is why holists presume that discovering the general rules that regulate the behaviour of populations, communities and ecosystems is a sensible and desirable goal of ecological research, and that formal research into communities and structures of ecosystems is useful and necessary.

Reductionist research traditions: in very general terms, reductionism comprises a set of ontological, epistemological and methodological claims about the relationships between the various domains of science. The underlying question of reductionism is whether the characteristics, concepts, explanations and methods of one branch of science (usually on a higher level of hierarchy) can be derived from or explained by their reduction to the concepts, explanations or methods of a different branch, i.e. one on a lower level of hierarchy.

With respect to ecology, reductionist (individualistic) research traditions (Gleason, 1926; Tansley, 1935; McIntosh, 1985) presume that ecological systems, populations and communities are, for the most part, defined by their response to the conditions of the local environment (both biotic and abiotic). At best, all characteristics of these systems represent the epiphenomenal statistical features of the populations of species that constitute them. The ecological attributes of the populations of species are best understood from the point of view of evolution - as inevitable results of natural selection or other evolutional mechanisms. Reductionists therefore shy away from attempts to trace the universal rules regulating large groups of ecological systems, as they believe that these systems are based on localityspecific, historically conditioned patterns of behaviour and conditions of the environment.

This duality of viewpoints has formed part of the context within which the majority of research into the fundamental questions of ecology, from the early decades of the twentieth century up until the present, has been conducted (e.g. Clements (1943), Gleason (1926) on the nature of community and succession). In this regard, the philosophy of ecology can define its fundamental problems as a set of metaphysical and epistemological questions. For instance, with regard to the metaphysical status of ecological subjects it can ask: What is the meaning of the terms 'species', 'population', 'community' or 'ecosystem'? Does ecology follow a set of general rules? If so, what are the causal relationships between ecological systems and what is the source of these relationships? Is the existence of such general rules in keeping with the premises of neo-Darwinism? With regard to epistemological modelling it asks: What is the appropriate role of theoretical modelling in ecological science? With regard to evolution and ecology it can pose the following questions: Can the present organisation and structure of communities be sufficiently explained by natural selection effective on the level of individual organisms alone?

This list of possible questions is incomplete, however, and most philosophers of science specialising in the philosophy of ecology have developed specific research programmes in direct or indirect response to some of the questions above (deLaplante et al., (eds.) 2011; Taylor, 2005; McIntosh, 1985). Nonetheless, there is never a single path leading to understanding. This paper offers an alternative point of view that draws on the belief that there is an inevitable degree of simplicity/complexity in all complex, evolving systems, and that if this degree is acknowledged, it can lead one to an understanding which is not only outlined in detail, but also clearly presented. In this overview I claim that if one is unable to clearly state the causes in their explanation of a phenomenon, their understanding is overly simple. On the other hand, if one's explanation requires more than just a set of clearly stated causes, it is excessively complex. The degree of understanding is based on an adequate integration theory, which should draw on empirical reality and should be formulated clearly, metaphorically and with examples. The unification of the principles of ecological, social and humanistic theory then becomes the fundamental precondition for achieving this level of understanding. 
What is more, it is necessary to unify these principles with the aim of simplifying them as much as possible, or even more.

At the end of the 1980s, the Royal Swedish Academy of Sciences founded the Beijer International Institute of Ecological Economics in order to create an interconnection not only between the fields of economy and ecology, but also between natural and social sciences in general. Karl-Göran Mäler, the director of the institute, started a tradition of annual meetings of economists, ecologists, mathematicians and other researchers from various branches of natural and social sciences and the humanities. These meetings took place on one of the Swedish islands. The programme of the meetings was never fixed; instead, the participants were invited to discuss one or two general questions, such as: What is poverty? What are the ecological and human consequences of rapid population growth? What is economic flexibility? What is ecological flexibility? How can values be measured?

The meeting participants gradually acquired an understanding of fields of research other than their own. What was at the core of these contemplative discussions was not a superficial polarising of opinions, which is characteristic of many scientific gatherings, but rather a heightened understanding of the strengths and weaknesses of the individual disciplines involved. It came as a surprise that the ecologists, social scientists and humanists all came to an agreement on several issues: global human and natural systems are dangerously strained; the methods employed in each of the disciplines are strikingly similar; the theories and mathematical models are uncannily alike and - insufficient! The critical differences emerged surprisingly slowly. The desire for dialogue and cooperation forced the specialists to avoid disagreement.

We should aim for a similar approach in the field of the philosophy of ecology - a multi-discourse intersectional foundation with a broad research agenda spanning a number of established scientific disciplines. It is our goal to highlight the interdisciplinary nature of the problems under investigation, and also the fact that the premises of the philosophy of ecology would be difficult to sustain and respect if they did not reflect the findings of contemporary research in the field of ecology, as well as in the field of philosophy. In order to plan a future for the Earth that would be sustainable in the long term, we need knowledge, and we need to establish a way of evaluating information and discarding irrelevant information in times of critical change.

How is new knowledge generated by competing sources of information and how is it incorporated into the extant body of knowledge? Which processes create novelty, which repress innovation and which encourage it? None of the disciplines mentioned above - ecology, economy, institutional theory, philosophy or ethics, as they are constructed today can address these fundamental questions of innovation, possibility and creation of new knowledge on its own.

A number of the basic needs within human society are derived from natural ecosystems. These needs represent a significant and recognised element of the structure of society. However, until recently, the fact that natural ecosystems are the basic life-sustaining force, without which human civilisation would be impossible, was much less known. The historical nature of the ecosystems' support for life on Earth, as well as the value of such support, was for the most part ignored until the ecosystems were damaged or lost. It was only through this damage or loss that the importance of ecosystems was revealed. For example, deforestation belatedly proved that forests play a crucial role in the regulation of the water cycle, especially in connection with flood mitigation, draught mitigation, the mitigation of the effects of wind and rain erosion or the filling-up of dams and irrigation canals. At present, the increasing influence of human activity on forests, marshes and other natural ecosystems 
threatens their ability to provide support for life. Changes in the exploitation of land, which lead to a loss of biodiversity, as well as to the disruption of biochemical cycles; the introduction of exotic species into places where they have not hitherto occurred (which is anthropogenic by nature); leakages of toxic substances; and the possibility of climate change; stratospheric ozone reduction, etc., are among the primary concerns of today.

Drawing on available data (in. Jacobsen and Hanley, 2009; Rudwidk, 2007; ShraderFrechette, 2001 and others) it is possible to conclude that:

- the activity of natural ecosystems is vital to sustain civilisation (culture)

- the activity of natural ecosystems is large-scale, and this complex unresearched area cannot be replaced with technology

- human activity disrupts the flow of ecosystem processes on a large scale

- if the current trend continues, humankind will dramatically alter practically all parts of the Earth and weaken the remaining natural ecosystems in the course of a couple of decades

In addition, contemporary scientific evidence points to the facts that:

- ecological balance, which has long-term value, can be disrupted by human activities that modify or destroy natural ecosystems

- a large number of species and populations (biodiversity) is necessary to sustain the processes and balance within ecosystems

- the function of many ecosystems could be restored if appropriate measures were taken immediately

Humankind is currently caught up in an escalating spiral of ecological, social and cultural destruction and material and spiritual deprivation. We are witnessing a homogenisation and unification of the human living world. Destruction and dependence have become the universal metaphors for uncontrolled population growth and dependence on a suicidal and alienating lifestyle, promoted primarily by Western culture. Philosophy cannot remain indifferent to this deep ecological and cultural crisis. However, philosophy cannot oversimplify this problem or even attempt to solve it single-handedly, either. The philosophy of ecology and of ecological crisis must avoid both the Scylla of simple answers and imperious solutions and the Charybdis of increasing, or even overpowering confusion and disorientation.

The opinion that philosophy is an abstract, theoretical field far removed from the concerns of everyday life is relatively widespread. A philosopher is usually envisioned as someone who is set apart from ordinary problems, and who devotes his/her time to pondering the question of the ultimate meaning of existence. Nevertheless, no matter how unrelated to our immediate concerns his/her activity may seem, fundamentally the philosopher deals with problems that are of importance for each one of us, be it directly or indirectly. In any case, it is the aim of philosophy to come up with a general and coherent understanding of the world and of the place humans and their concerns occupy within this world. Are these concerns so far removed from everyday life? Sometimes they are, sometimes they are not. With regard to the philosophy of ecology, they are indeed extremely relevant. 
The philosophy of ecology is slowly becoming accepted as a legitimate area of philosophical enquiry. ${ }^{2}$ It lies at the intersection of ecology and philosophy. Philosophical knowledge can reflect ecology, or rather ecological theories, in a number of ways (as explained elsewhere). Philosophy can aid in the development of better models of hypothesis testing in ecology. Philosophy can also help ecologists to understand the roles and limitations of the so-called mathematical models, when used in ecology. Case studies on ecology can shed light on old philosophical problems, such as the analysis and understanding of theoretical concepts, including ecologism, biodiversity, ecological restoration and ecological stability. ${ }^{3}$ Currently, we can also count the formulation of problems connected with the justification of moral normativity of environments and their significance for ecological ethics among such philosophical issues. This is of great importance for our better understanding of how nature and culture are mutually interlinked within the discussion of pressing problems, such as climate change, the protection of the diversity of species or the management of sustainable resources.

We believe that even contemporary geopolitical problems mirror the issues discussed in the field of the philosophy of ecology. It is our aim to inspire cooperation and an exchange of ideas and topics between ecology and philosophy, and thus help map out a programme of work within the philosophy of ecology. The importance of ecology for human prosperity and for biodiversity should be (and, indeed, is) clearly visible in conservation biology, environmental biology and ecological ethics. Ecology offers many opportunities for answering universal questions relating to numerous traditional philosophical concerns, such as complexity, life, arbitrariness, holism, reductionism, etc. This gives rise to a need for a new ontology, ${ }^{4}$ whose premises can be discovered in different forms of non-reductionist naturalism, which respect the fact of the interconnection of people and other inhabitants of the Earth. To quote J. Passmore "... in order for the 'new metaphysics' not to distort facts, it has to be naturalistic, but it cannot be reductionist. To develop such metaphysics is, I believe, the most complicated of the tasks that lie ahead of philosophy." (Passmore, 1975: 261) This

2 David R. Keller, Frank B. Golley (eds.). The Philosophy of Ecology: From Science to Synthesis. 2000. This volume is the first comprehensive anthology dedicated to the philosophy of ecology. It was edited by an ecologist and a philosopher. It illustrates the range of possible philosophical approaches which are available to ecologists, and it lays the foundations for a deeper understanding of thinking within the realm of the philosophy of ecology. The problems discussed in this anthology include: challenges of defining scientific ecology; the distinction between scientific ecology and other forms of ecological thinking; the ontology of ecological subjects and processes; the analysis of selected concepts (i.e. community, stability, diversity, niche).

${ }^{3}$ The term 'ecosystem' was coined in 1935 by Sir Arthur George Tansley, who defined it as the whole system, including not only the organism-complex, but also the whole complex of physical factors forming what we call the environment, or a biome-habitat in the broadest sense. Tansley used the term 'ecosystem' to denote the physical description of a community in its environment. Only in the last decade, seventy years after the introduction of the term and forty years after the explosive increase of interest in ecosystem studies, has the importance of the knowledge generated by this scientific field become obvious. This knowledge is important not only on the level of science, but also on the level of politics. Therefore, the formulation of a definition of this term is not only a scientific problem, but can also serve as an impetus to re-evaluate the philosophical aspects of the delimitation of theoretical terms.

${ }^{4}$ A reference is made here to the evolutionary ontology developed by professor J. Šmajs (1995). In his study Sebastian Malet (2012) introduces a relational ontology, which could serve as an alternative formulation of the understanding of nature, which resonates with the ecological knowledge of the ontology of mutual interconnection and dependence, without running the risk of slipping into reductionism and solipsism. 
is the battleground and the challenge for philosophy and for its productive reflections on ecology.

It follows from the above that it is possible to understand the philosophy of ecology as a field employing a specific and direct way of ecological and humanistic research and management. This approach should naturally draw on the philosophical theories and principles developed by theoretical philosophy, applied philosophy and applied ethics (e.g. bioethics, animal ethics, ecological ethics and environmental ethics). On the whole, such philosophy has a broader scope and integrates a much larger field than any of the disciplines and sub-disciplines mentioned above. The research agenda (which is interdisciplinary by nature) can be effective as long as it results from an organised ongoing discussion, carried out across natural sciences, social sciences, the humanities and the field of nature conservation. Speaking very generally, it is no longer an area of purely philosophical reflection, or a purely scientific one. Rather, it is an intersection of practical and professional research which attempts to produce tangible results in the form of a conceptual contribution to the solution of moral and philosophical problems in ecology, and in the reflection on and management of biodiversity, while simultaneously attempting to understand the strengths and weaknesses of the individual disciplines involved.

We are well aware of the fact that even the most pragmatic of goals for the development of methods and attraction of investments in the field of the philosophy of ecology needs a theoretical basis which would integrate ecological and philosophical theory with the theory of evolution, and which would bridge the gap between these fields that has arisen from the theoretical limitations currently present in each of them.

\section{References}

- Clemens, F. E. (1935). Social origins and processes among plants. In C. Murchison (ed.), A Handbook of Social Psychology Vol 1 (pp. 22-48). Worcester: Clark University Press.

- Clemens, F. E. (1943). Succession in the plant community. In R. D. McKenzie (ed.), Readings in Human Ecology (pp. 439-440). Ann Arbor: George Wahr.

- deLaplante, K., Brown, B., \& Peacock, K.A. (eds.), (2011). Handbook of the Philosophy of Science. Volume 11 Philosophy of Ecology. : Elsevier.

- Gleason, H. A. (1926). The Individualistic Concept of the Plant Association. Bulletin of the Torrey Botanical Club, 53(1), 7-26. Retrieved from

http://www.jstor.org/stable/2479933?origin=crossref

http://dx.doi.org/10.2307/2479933

- Jacobsen, J. B., \& Hanley, N. (2009). Are There Income Effects on Global Willingness to Pay for Biodiversity Conservation. Environ Resource Econ, 43(2), 137-160. Retrieved from http://link.springer.com/10.1007/s10640-008-9226-8 http://dx.doi.org/10.1007/s10640-008-9226-8

- Keller, D. R., \& Golley, F. B. (eds.), (2000). The philosophy of ecology: From science to synthesis. Athens, Ga: University of Georgia Press.

- Kingsland, S. E. (2005). The Evolution of American Ecology, 1890-2000. Johns Hopkins University Press: Baltimore. 
- Kuhn, T. S. (1977). Essential Tension. Chicago: University of Chicago Press. Retrieved from http://link.aip.org/link/?AJP/47/568/1\&Agg=doi http://dx.doi.org/10.1119/1.11776

- Latour, B. (2003). Nikdy sme neboli moderní. Kalligram: Bratislava.

- Malet, S. (2012). From Knowledge to Ontological Awakening: Thinking Nature as Relatedness. The Trumpeter, 28(1),

- McIntosh, R. P. (1985). The Background of Ecology: Concept and Theory. Cambridge: Cambridge University Press. Retrieved from http://ebooks.cambridge.org/ref/id/СВ09780511608537 http://dx.doi.org/10.1017/CBO9780511608537

- Passmore, J. (1975) Attitudes to Nature. In R. S. Peters (Ed.), Nature and Conduct. London: Macmillan.

- Rudwidk, M. J. S. (2007). Bursting the Limits of Time: The Reconstruction of Geohistory in the Age of Re-volution. Chicago: University of Chicago Press.

- Shrader-Frechette, K. S., \& McCoy, E. D. (1993). Method of Ecology: Strategies for Conservation. Cambridge: Cambridge University Press. Retrieved from http://ebooks.cambridge.org/ref/id/CBO9780511623394 http://dx.doi.org/10.1017/CB09780511623394

- Shrader-Frechette, K. (2001) Ecology. In D. Jamieson (Ed.), A Companion to Environmental Philosophy (pp. 304-315). In: Blackwell. Retrieved from http://doi.wiley.com/10.1002/9780470751664 http://dx.doi.org/10.1002/9780470751664

- Shepard, P. (1969) Ecology and Man: A Viewpoint. In P. Shepard \& D. McKinley (Eds.), The Subversive Science. Boston: Houghton Miffin.

- Šmajs, J. (1995). Ohrožená kultura. Zvláštní vydáni... Brno: Brno.

- Tansley, A. G. (1935). The Use and Abuse of Vegetational Concepts and Terms. Ecology, 16(3), 284-307. Retrieved from http://www.jstor.org/stable/1930070?origin $=$ crossref http://dx.doi.org/10.2307/1930070

- Taylor, P. J. (2005). Unruly Complexity: Ecology, Interpretation, Engagement. Chicago: University of Chicago Press. Retrieved from http://www.bibliovault.org/BV.landing.epl?ISBN=9780226790367 http://dx.doi.org/10.7208/chicago/9780226790398.001.0001 